\title{
The effects of cereal type and a-tocopherol level on milk production, milk composition, rumen fermentation, and nitrogen excretion of spring-calving dairy cows in late lactation
}

\author{
Z. C. McKay, ${ }^{1}$ F. J. Mulligan, ${ }^{2}$ M. B. Lynch,,${ }^{1}$ G. Rajauria, ${ }^{1}$ C. Miller, ${ }^{3}$ and K. M. Pierce ${ }^{1 *}$ \\ ${ }^{1}$ School of Agriculture and Food Science, University College Dublin, Lyons Research Farm, Lyons Estate, Celbridge, Naas, Co. Kildare, \\ Ireland W23 ENY2 \\ ${ }^{2}$ School of Veterinary Medicine, University College Dublin, Belfield, Dublin 4, Ireland D04 W6F6 \\ ${ }^{3}$ Gain Feeds, Glanbia Plc, Bridge Street, Portlaoise, Ireland R32 ND7A
}

\section{ABSTRACT}

Grass-based production systems use concentrate supplementation primarily when pasture quality and availability have declined. Barley is a common concentrate ingredient; however, oat grain grows well in Ireland, is a source of lipids and fiber, and may provide an alternative to barley. The antioxidant $\alpha$-tocopherol $(\alpha-$ TOC) plays a role in cell membrane structure, and it has the potential to improve tight junction structures of the mammary gland that deteriorate in late lactation. The objective of this research was to investigate the effect of cereal type and $\alpha$-TOC level on milk yield, milk composition, rumen fermentation, and $\mathrm{N}$ excretion in late-lactation dairy cows at pasture and when housed indoors on grass silage. Forty-eight Holstein Friesian dairy cows were blocked on days in milk $(+185 \mathrm{~d}$ in milk) and balanced for parity, pre-experimental milk yield, milk composition, and body condition score and assigned to 1 of 4 dietary treatments in a randomized complete block design $(\mathrm{n}=12)$. The dietary treatments were control $(\mathrm{C})$ base diet; base diet + barley-based concentrate + low $\alpha$-TOC $(350 \mathrm{IU} / \mathrm{kg})(\mathrm{B})$; base diet + oat-based concentrate + low $\alpha$-TOC $(350 \mathrm{IU} / \mathrm{kg})(\mathrm{O})$; and base diet + oat-based concentrate + high $\alpha$-TOC $(1,050 \mathrm{IU} / \mathrm{kg})(\mathrm{O}+\mathrm{T})$. Following a 14-d acclimation period, diets were offered for a 49-d experimental period at pasture (P1) and a 21-d experimental period indoors (P2). The base diet was grazed grass in $\mathrm{P} 1$ and grass silage in $\mathrm{P} 2$. In $\mathrm{P} 2$, cows on $\mathrm{C}$ also received $2.65 \mathrm{~kg}$ (dry matter) of a standard concentrate. In P1, supplementation increased milk and milk solids yield (B: 20.7 $\mathrm{kg} / \mathrm{d}, 1.74 \mathrm{~kg} / \mathrm{d} ;$ O: $20.6 \mathrm{~kg} / \mathrm{d}, 1.81 \mathrm{~kg} / \mathrm{d} ; \mathrm{O}+\mathrm{T}: 20.5$

Received January 8, 2019.

Accepted April 8, 2019.

*Corresponding author: karina.pierce@ucd.ie $\mathrm{kg} / \mathrm{d}, 1.77 \mathrm{~kg} / \mathrm{d}$, respectively) compared with $\mathrm{C}(17.8$ $\mathrm{kg} / \mathrm{d}, 1.60 \mathrm{~kg} / \mathrm{d}$ ). Cows offered B had a lower milk fat $(4.60 \%)$ concentration than $\mathrm{C}(5.00 \%)$ and $\mathrm{O}(4.90 \%)$. In P2, cereal type and $\alpha$-TOC level did not alter milk production. In conclusion, concentrate supplementation increased milk and milk solids yield and cows offered $\mathrm{O}$ had a higher milk fat concentration than cows offered B. Increasing the level of $\alpha$-TOC had no major effect on production parameters measured in $\mathrm{P} 1$ or in $\mathrm{P} 2$.

Key words: dairy cow, concentrate supplementation, late lactation, oat grain, $\alpha$-tocopherol

\section{INTRODUCTION}

Milk production in Ireland is produced primarily from a low-cost pasture-based system aimed at maximizing the amount of grazed grass in the cow's diet (McEvoy et al., 2008; Hanrahan et al., 2017). However, because grass growth is seasonal, grass quality and availability can be poor in the autumn (McEvoy et al., 2008), which can reduce milk production and negatively alter milk composition (Burke et al., 2008). Additionally, following the abolition of the European Union's milk quota, cow numbers in Ireland have increased (CSO, 2017) and cows are milking later into lactation (CSO, 2015), exacerbating the issues that arise with late-lactation milk production and quality (Phelan et al., 1982; Downey and Doyle, 2007). Subsequently, interest has increased in supplementation at pasture in the autumn as a means of supporting milk production and negating issues of milk quality at that time.

Concentrate supplementation can be offered at pasture in autumn to increase milk production, improve milk composition, and increase lactation length (Kellaway and Porta, 1993; Kennedy et al., 2005) as well as improve nitrogen utilization efficiency compared with pasture-only diets (Reid et al., 2015). However, research to date has focused on barley (Reid et al., 2015), which is a common high-energy cereal grown in 
Ireland (Theurer, 1986). Corn grain is also a common energy source included in concentrate feeds in Ireland; however, McKay et al. (2017) observed increased milk and milk solids yield from late-lactation grazing dairy cows offered a barley-based concentrate compared with a corn grain-based concentrate. Oat grain is a cereal crop that is suited to growing in Ireland's temperate climate (Hackett, 2018). Oat grain is higher in lipids and fiber, which makes it a potential complementary feed for dairy cows offered autumn pasture (Ekern et al., 2003; Hackett, 2018) to improve milk yield and milk composition, particularly milk fat concentration, which is known to decline with increasing cereal-based concentrate supplementation (O'Brien et al., 1996; Bargo et al., 2003). Offering an oat-based supplement to dairy cows as a supplement to grass silage-based and complete diets has been found to increase milk yield, milk protein yield (Ekern et al., 2003), and milk fat concentration (Moran, 1986); however, little research has been completed on the use of oats in grazing systems.

In late lactation, milk yield naturally begins to decline, with a reduction in secretory epithelial cell numbers due to apoptotic cell death in the mammary gland (Wilde and Knight, 1989; Stefanon et al., 2002). During this process, tight junctions between epithelial cells start to become leaky, which allows the passage of water, small molecules, and ions between milk and interstitial fluid (Nguyen and Neville, 1998; Matter and Balda, 2003). Consequences include reduced milk yield, milk lactose, and milk casein concentration and an increase in milk SCC of cows in late lactation (Stelwagen et al., 1997; Politis et al., 2004). One of the main functions of $\alpha$-tocopherol ( $\alpha$-TOC) centers on its antioxidant properties, but it also has a role in cell membrane structure (Charmley et al., 1993). Cell membranes are composed of lipid bilayers, particularly PUFA, and it has been reported that $\alpha$-TOC protects the PUFA in cell membranes from reactive oxygen species (Putnam and Comben, 1987; Rice and Kennedy, 1988). Studies have found that $\alpha$-TOC improved the structure and function of renal and kidney tight junctions in rats and dogs, respectively (Arreola-Mendoza et al., 2009; Fusi et al., 2018), while research carried out in pigs (Monahan et al., 1989) and beef cattle (Liu et al., 1995) revealed that dietary vitamin E supplementation significantly increased the $\alpha-T O C$ concentration in muscles and suggested that $\alpha$-TOC has a role in protecting cell membranes from oxidation.

The objective of this research was to investigate the effect of cereal type and $\alpha$-TOC level on milk yield, milk composition, rumen fermentation, and $\mathrm{N}$ excretion in late-lactation dairy cows at pasture and when housed indoors on grass silage.

\section{MATERIALS AND METHODS}

\section{Cows, Treatments, and Experimental Design}

The Animal Research Ethics Committee at University College Dublin (UCD) approved all the procedures described in this experiment. These procedures were conducted under experimental license (AE189821/ P106) from the Health Products Regulatory Authority under the European directive 2010/63/EU and S.I. No. 543 of 2012. Each person who carried out procedures on experimental animals during the course of this experiment was licensed to do so by means of individual authorization from the Health Products Regulatory Authority.

Forty-eight dairy cows (Bos taurus strain Holstein Friesian) were selected from the spring-calving dairy herd at UCD Lyons Research Farm, Lyons Estate, Celbridge, Naas, Ireland ( $\left.53^{\circ} 17^{\prime} 56^{\prime \prime} \mathrm{N}, 6^{\circ} 32^{\prime} 18^{\prime \prime} \mathrm{W}\right)$. The cows were blocked on DIM and balanced for parity, milk yield, milk composition (fat content, protein content, and fat and protein in kilograms) and BCS. The study was divided into 2 periods. Period 1 (P1) was a 49-d grazing period with cows (212-261 DIM) assigned to 1 of 4 dietary treatments in a randomized complete block design $(\mathrm{n}=12)$ with a base diet of grazed grass. The dietary treatments (Table 1 ) were the control base diet $(\mathbf{C})$; base diet + barley-based concentrate + low $\alpha$-TOC $(350 \mathrm{IU} / \mathrm{kg})(\mathbf{B})$; base diet + oat-based concentrate + low $\alpha$-TOC $(350 \mathrm{IU} / \mathrm{kg})(\mathbf{O})$; and base diet + oat-based concentrate + high $\alpha$-TOC $(1,050 \mathrm{IU} / \mathrm{kg})$ $(\mathbf{O}+\mathbf{T})$. The formulated supplemented levels of $\alpha$-TOC (not including base diet $\alpha$-TOC) resulted in a total dietary intake of 1,050 IU of $\alpha-T O C / d$ for B and $\mathrm{O}$ and a higher level of 3,150 IU of $\alpha-\mathrm{TOC} / \mathrm{d}$ for $\mathrm{O}+\mathrm{T}$. The type of $\alpha$-TOC offered was all-rac $\alpha$-tocopheryl acetate from DSM Nutritional Products (Heerlen, the Netherlands).

Milk yield, milk composition, BCS, rumen fermentation parameters, and BW measurements were taken before treatment for use as covariates in the statistical model if required. Cows had a 14-d dietary acclimation period before starting P1. Measurements were then taken weekly for $8 \mathrm{wk}$ (September 12 to October 31) for BCS, milk production, milk composition, blood glucose, BW, and rumen health parameters, such as rumen $\mathrm{pH}, \mathrm{VFA}$, and $\mathrm{NH}_{3}$ concentration, and during wk 3 for pasture DMI and N partitioning.

At the end of the grazing season (November 1, 2017), cows were housed and offered a base diet of grass silage (P2) for $21 \mathrm{~d}$. Period 2 allowed for further investigation into the effect of dietary treatment on milk production and composition and rumen fermentation when cows were later in lactation (275-289 DIM) and were 
Table 2. Chemical composition ( $\mathrm{g} / \mathrm{kg}$ of DM unless otherwise noted) of experimental feedstuffs offered in periods 1 and 2

\begin{tabular}{|c|c|c|c|c|c|c|}
\hline Chemical composition & \multicolumn{6}{|c|}{ Experimental feedstuff } \\
\hline $\mathrm{CP}$ & 217 & 172 & 169 & 171 & 170 & 199 \\
\hline Ash & 93 & 98 & 95 & 105 & 87 & 73 \\
\hline NDF & 499 & 314 & 349 & 361 & 427 & 223 \\
\hline Water-soluble carbohydrates & 139 & - & - & - & 138 & - \\
\hline Starch & - & 211 & 181 & 170 & - & 233 \\
\hline Gross energy (MJ/kg) & 17.4 & 17.1 & 17.4 & 17.3 & 17.9 & 17.5 \\
\hline$\alpha-\mathrm{TOC}(\mathrm{IU} / \mathrm{kg})$ & 44 & 259 & 246 & 977 & 31 & 20 \\
\hline
\end{tabular}

${ }^{1}$ Period $1=49$-d period at pasture.

${ }^{2}$ Period $2=21$-d period indoors on grass silage.

${ }^{3}$ Barley-based concentrate +350 IU of $\alpha$-tocopherol $(\alpha$-TOC) $/ \mathrm{kg}$.

${ }^{4}$ Oat-based concentrate $+350 \mathrm{IU}$ of $\alpha-\mathrm{TOC} / \mathrm{kg}$.

${ }^{5}$ Oat-based concentrate $+1,050 \mathrm{IU}$ of $\alpha-\mathrm{TOC} / \mathrm{kg}$.

age pregrazing herbage mass was $1,646 \mathrm{~kg}$ of $\mathrm{DM} / \mathrm{ha}$ (above $4 \mathrm{~cm}$ ), with an average pregrazing compressed sward height of $10 \mathrm{~cm}$ (above ground level). The average postgrazing mass was $441 \mathrm{~kg}$ of $\mathrm{DM} /$ ha with an average postgrazing compressed sward height of $5 \mathrm{~cm}$. Grass chemical composition was determined using the quadrat and shears method as described by Whelan et al. (2012a). Pregrazing quadrat samples were collected by taking 2 quadrat $(0.5 \times 0.5 \mathrm{~m}$ quadrat $)$ cuts per allocation (twice per day) and harvesting to $4 \mathrm{~cm}$ to determine chemical composition. These samples were pooled weekly for analysis (DM, gross energy, ether extract, ash, and $\mathrm{CP}$ ), NDF, ADF, and water-soluble carbohydrates (WSC), and the results are shown in Table 2 and Figure 1. Weekly concentrate samples were taken and pooled for the duration of the trial to determine DM and then ground for use in proximate analysis, NDF, ADF, and starch (Table 2). During P2, silage samples were taken daily and pooled weekly for proximate analysis, NDF, ADF, and WSC (Table 2).

Cow Measurements. Cows were milked twice daily at 0700 and $1500 \mathrm{~h}$ (a.m. and p.m. milkings, respectively). Milk yield measurement and composite milk sample collection was facilitated using the Weighall milk metering and sampling system (Dairymaster). Milk samples were taken once weekly from successive a.m. and p.m. milkings and pooled on a per-cow basis according to milk yield (Figure 2). Milk samples were sent for analysis of fat, protein, casein, lactose, SCC, and urea to a commercial milk laboratory (National Milk Laboratories Ltd., Wolverhampton, UK).

Cows were weighed twice daily after milking using an electronic scales as they left the parlor through the automatic drafting unit (Dairymaster) and averaged per day. Body condition score was determined once weekly, by the same pretrained operator, using a scale of 1 to 5 with 0.25 increments according to Edmonson et al. (1989).

Blood samples were collected by jugular venipuncture once weekly following the p.m. milking to coincide with milk sampling, rumen fluid sampling, and BCS. Blood samples for glucose analysis were harvested into 4-mL glucose Vacutainer tubes (368921; BD, Plymouth, UK), which were stored on ice and centrifuged at 2,100 $\times$ $g$ for $20 \mathrm{~min}$ at $4^{\circ} \mathrm{C}$ for extraction of blood plasma. The blood plasma was drained off and frozen at $-20^{\circ} \mathrm{C}$ pending further analysis.

Rumen fluid samples were harvested by Flora Rumen scoop oral esophageal sampler (Prof-Products, Guelph, ON, Canada) once weekly. Sampling was carried out after the p.m. (1500 h) milking, at $1600 \mathrm{~h}$. Rumen fluid samples were analyzed immediately for $\mathrm{pH}$ (Phoenix Instrument EC-25 pH/Conductivity Portable Meter). Samples were strained through 4 layers of cheese cloth; then, a 4-mL aliquot was taken using an automatic pipette, mixed with $1 \mathrm{~mL}$ of trichloroacetic acid (500 $\mathrm{g} / \mathrm{L})$, cooled on ice, and then stored $\left(-20^{\circ} \mathrm{C}\right)$ pending analysis for VFA and $\mathrm{NH}_{3}$.

Nitrogen Partitioning Study. Nitrogen partitioning was determined during wk 2 to 3 of the study (average 226 DIM). Pasture DMI and N excretion were estimated over a 6 -d period. Based on the method of Dove and Mayes (2006), cows were dosed with a paper bolus impregnated with $500 \mathrm{mg}$ of the $n$-alkane $n$-dotriacontane (C32), for a period of $12 \mathrm{~d}$ following a.m. and p.m. milkings. From d 6 to 12, samples of the concentrates, pasture, milk, and feces were collected. Daily concentrate samples were collected and pooled for 
the 6 -d period and stored at $-20^{\circ} \mathrm{C}$ pending proximate analysis. Pasture samples were collected every morning and evening using a quadrat and handheld shears. These samples were immediately dried at $55^{\circ} \mathrm{C}$ for 48 h. Fecal samples were collected during observation periods as cows naturally defecated and if not, samples were collected per rectum and immediately placed in a forced air oven at $55^{\circ} \mathrm{C}$ for $72 \mathrm{~h}$ or until dry. To determine $\mathrm{N}$ partitioning, samples of milk were collected during a.m. and p.m. milkings and pooled according to milk yield. Milk samples were sent for analysis of fat, protein, casein, lactose, SCC, and urea to a commercial milk laboratory (National Milk Laboratories Ltd.).

\section{Sample Analysis}

Feed and Fecal Sample Analysis. Pasture, silage, concentrate, and fecal (Whelan et al., 2012a) samples were dried in a forced air oven at $55^{\circ} \mathrm{C}$ and were ground in a hammer mill fitted with a 1-mm screen (lab mill, Christy Turner, Suffolk, UK). The DM content of samples was determined by drying at $105^{\circ} \mathrm{C}$ overnight
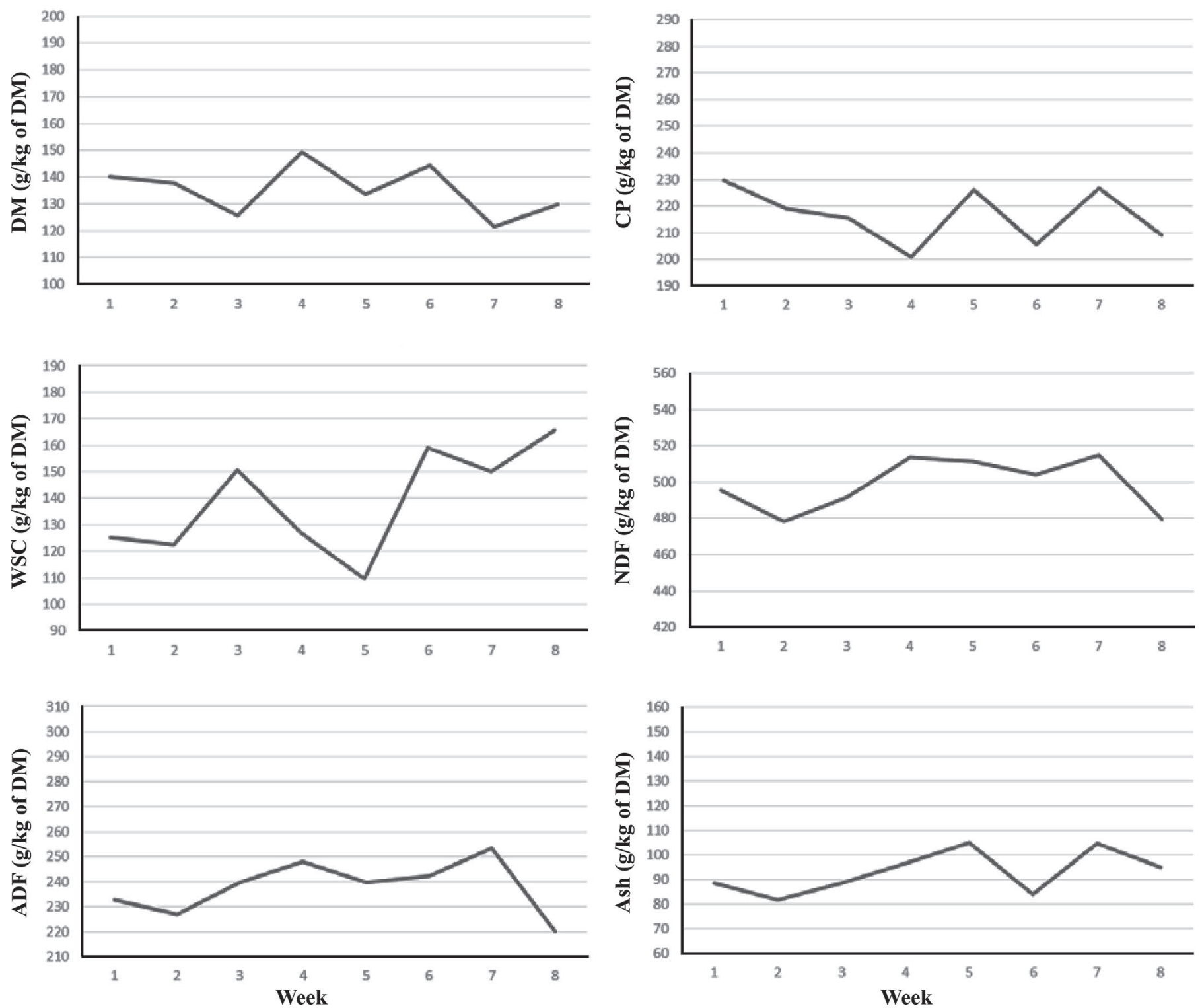

Figure 1. Changes in autumn pasture quality offered to dairy cows in period 1 (wk $1=$ September 12 and wk $8=$ October 31 ). Standard deviations across the 8 -wk experimental period were $\pm 9.5 \mathrm{~g} / \mathrm{kg}$ of DM, $\pm 10.7 \mathrm{~g} / \mathrm{kg}$ of CP, $\pm 20.2 \mathrm{~g} / \mathrm{kg}$ of water-soluble carbohydrate, $\pm 14.7 \mathrm{~g} /$ $\mathrm{kg}$ of $\mathrm{NDF}, \pm 10.9 \mathrm{~g} / \mathrm{kg}$ of $\mathrm{ADF}$, and $\pm 8.8 \mathrm{~g} / \mathrm{kg}$ of ash. 


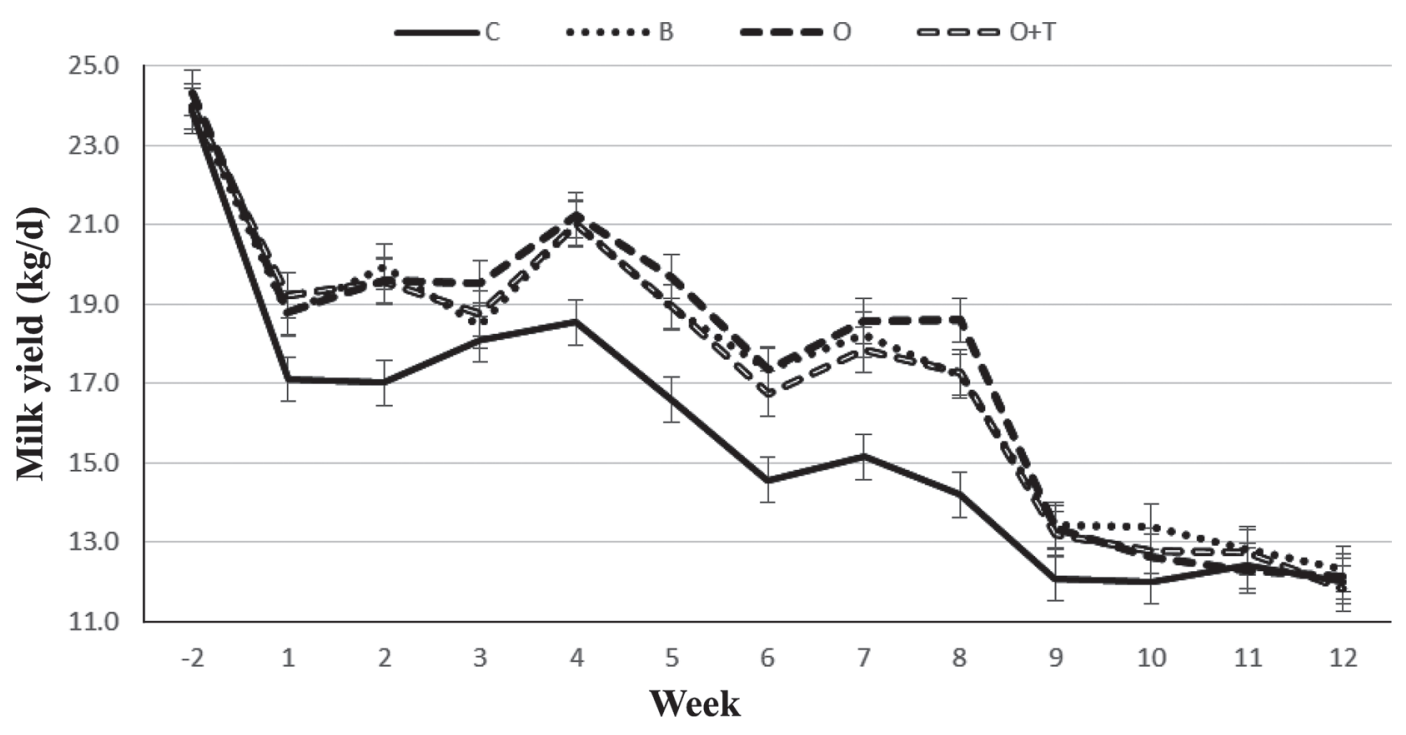

Figure 2. Changes in milk yield from the acclimation period (wk -2) over the 8-wk grazing period (wk 1-8: September 12 to October 31) followed by the second acclimation period (wk 8-9) and a 3-wk indoor period (wk 10-12: November 14-28). Control, pasture only (C); pasture $+2.65 \mathrm{~kg}(\mathrm{DM})$ of barley-based concentrate $+350 \mathrm{IU}$ of $\alpha$-tocopherol $(\alpha-\mathrm{TOC}) / \mathrm{kg}(\mathrm{B}) ;$ pasture $+2.65 \mathrm{~kg}(\mathrm{DM})$ of oat-based concentrate +350 $\mathrm{IU}$ of $\alpha-\mathrm{TOC} / \mathrm{kg}(\mathrm{O})$; pasture $+2.65 \mathrm{~kg}(\mathrm{DM})$ of oat-based concentrate $+1,050 \mathrm{IU}$ of $\alpha-\mathrm{TOC} / \mathrm{kg}(\mathrm{O}+\mathrm{T})$. Error bars detail SEM.

(16 h minimum; method 930.15, AOAC International, 2005). Ash was determined following combustion in a muffle furnace (Nabertherm $\mathrm{GmbH}$, Lilienthal, Germany) at $550^{\circ} \mathrm{C}$ for $5.5 \mathrm{~h}$ (method 942.05 , AOAC International, 2005). The $\mathrm{CP}$ content of the pasture, concentrate, and fecal samples was determined by combustion (FP 528 Analyzer, Leco Corp., St. Joseph, MI; method 990.03, AOAC International, 2005). Gross energy was determined by bomb calorimetry (Parr 1281 bomb calorimeter, Parr Instrument Company, Moline, IL), and ether extract content was determined using Soxtec instruments (Tecator, Höganäs, Sweden) and light petroleum ether. Neutral detergent fiber and ADF were determined using the method of Van Soest et al. (1991) adopted for use in the Ankom 220 Fiber Analyzer (Ankom Technology, Macedon, NY). This method included a thermostable $\alpha$-amylase and sodium sulfide, but residual ash was not determined. Starch content of feed samples was analyzed using the Megazyme Total Starch Assay Procedure (product no: K-TSTA; Megazyme International Ireland Ltd., Wicklow, Ireland). The concentration of WSC was determined as described by Dubois et al. (1956). The DL- $\alpha$-tocopherol acetate content of feed samples was analyzed by ALS Global (Clonmel, Ireland) using the United Kingdom Accreditation Service method of extracting DL- $\alpha$-tocopherol acetate from the feed using an ammonia/methanol solution at $60^{\circ} \mathrm{C}$, shaking with chloroform, and then filtering. The diluted extract was tested by reverse-phase HPLC with fluorescence detection. Following chemical analysis, the actual levels of DL- $\alpha$-tocopherol acetate supplemented in the concentrates offered were 777,738 , and 2,931 $\mathrm{IU} / \mathrm{d}$ for $\mathrm{B}, \mathrm{O}$, and $\mathrm{O}+\mathrm{T}$, respectively. One milligram of feed DL- $\alpha$-tocopherol acetate is the same as $1 \mathrm{IU}$ of DL- $\alpha$-tocopherol acetate, which is accepted as the international standard (McDowell, 2000).

Cow Measurement Analysis. Concentrations of milk fat, protein, lactose, casein, urea, and SCC were determined in a commercial milk laboratory (National Milk Laboratories Ltd.) using mid-infrared spectrometry (MilkoScan FT6000, Foss Analytical A/S, Hillerød, Denmark; Soyeurt et al., 2006). The DL- $\alpha$-tocopherol acetate content of milk samples was also analyzed by ALS Global by the same method used for the feed samples. Values for ECM, $40 \mathrm{~g} / \mathrm{kg}$ FCM, and fat- and protein-corrected milk (FPCM) were calculated as follows: $\mathrm{ECM}=(0.03273 \times$ milk yield, $\mathrm{kg})+(7.65 \times$ milk protein, $\mathrm{kg})+(12.97 \times$ milk fat, $\mathrm{kg})($ Tyrrell and Reid, $1965) ; 40 \mathrm{~g} / \mathrm{kg} \mathrm{FCM}=(0.4 \times$ milk yield, $\mathrm{kg})+(15 \times$ fat yield, $\mathrm{kg}$ ) (Gaines and Davidson, 1923); FPCM = $(0.337+0.116 \times$ milk fat, $\%+0.06 \times$ milk protein, $\%)$ $\times$ milk yield, $\mathrm{kg}$ (Sjaunja et al., 1990).

Blood samples were analyzed for glucose in the UCD veterinary clinical pathology laboratory (School of Veterinary Medicine, UCD, Belfield, Dublin, Ireland) using Randox Kits according to the manufacturer's instructions and an RX Imola analyzer (Randox Laboratories, Crumlin, UK).

Rumen fluid was allowed to thaw for $16 \mathrm{~h}$ at $4^{\circ} \mathrm{C}$ and was centrifuged at $2,100 \times g$ for $10 \mathrm{~min}$ at $4^{\circ} \mathrm{C}$. 
One milliliter of supernatant was diluted $1: 5$ with distilled $\mathrm{H}_{2} \mathrm{O}$ and then centrifuged at $1,600 \times g$ for $15 \mathrm{~min}$ at $4^{\circ} \mathrm{C}$. Two hundred microliters of supernatant was combined with 3 reagents and then used to determine $\mathrm{NH}_{3}$ concentrations using a spectrophotometer. Rumen fluid was prepared for VFA analysis by mixing 250 $\mu \mathrm{L}$ of rumen fluid with $3.75 \mathrm{~mL}$ of distilled $\mathrm{H}_{2} \mathrm{O}$ and then adding $1 \mathrm{~mL}$ of internal standard solution $(0.5 \mathrm{~g}$ 3 -methylvaleric acid in $1,000 \mathrm{~mL}$ of $0.15 \mathrm{M}$ oxalic acid). The resulting solution was centrifuged at 1,600 $\times g$ and filtered through a syringe tip filter (polytetrafluoroethylene, $13-\mathrm{mm}$ diameter, $0.45 \mu \mathrm{m}$ ) into $2-\mathrm{mL} \mathrm{GC}$ vials. Concentrations of VFA were determined using GC (Varian 3800 GCL; Varian Inc., Palo Alto, CA) fitted with a $15-\mathrm{m}$ capillary column with an i.d. of 0.53 $\mathrm{mm}$ coated with $1.20 \mu \mathrm{m}$ of acid-modified polyethylene glycol (EC-1000; Grace Davison Discovery Sciences, Lancashire, UK).

Nitrogen Partitioning Study. Pasture DMI was estimated by extracting $n$-alkanes from pasture, concentrate, and feces samples according to the method of Dove and Mayes (2006). Following extraction, samples were analyzed for concentrations of $n$-alkanes by GC using a Varian 3800 GLC (Varian Inc., Palo Alto, CA) fitted with a 30-m capillary column with an i.d. of 0.53 $\mathrm{mm}$ coated with $0.5 \mu \mathrm{m}$ of dimethyl polysiloxane (SGE Analytical Science Pty Ltd., Ringwood, Victoria, Australia). These data were used to calculate $\mathrm{N}$ partitioning as follows: $\mathrm{N}$ intake $(\mathrm{g})=(\mathrm{kg}$ of pasture $\mathrm{DMI} \times \mathrm{g}$ of $\mathrm{N} / \mathrm{kg}$ of DM pasture $)+(\mathrm{kg}$ of concentrate DMI $\times \mathrm{g}$ of $\mathrm{N} / \mathrm{kg}$ of DM concentrate); fecal $\mathrm{N}(\mathrm{g})=\mathrm{kg}$ of fecal $\mathrm{DM}$ excretion $\times \mathrm{g}$ of $\mathrm{N} / \mathrm{kg}$ of DM feces; milk $\mathrm{N}(\mathrm{g})=$ $\mathrm{kg}$ of milk yield $\times \mathrm{g}$ of $\mathrm{N} / \mathrm{kg}$ of milk; and urine $\mathrm{N}(\mathrm{g})$ $=\mathrm{N}$ intake $(\mathrm{g})-$ fecal $\mathrm{N}(\mathrm{g})-$ milk $\mathrm{N}(\mathrm{g})$ (van Vuuren et al., 1993).

\section{Statistical Analysis}

Data were checked for adherence to the normal distribution and homogeneity of variance using histograms and formal statistical tests as part of the Univariate procedure of SAS version 9.3 (2012; SAS Institute Inc., Cary, NC ). The natural logarithm transformation of milk SCC was used to normalize the distribution. The transformed data were used to calculate $P$-values. However, the corresponding least squares means and standard errors of the untransformed data are presented in results for clarity (Al Ibrahim et al., 2010). Analysis of data was conducted using Proc Mixed of SAS (SAS Institute Inc., 2012). The model included the fixed effects of treatment and time and their interaction. The interaction treatment $\times$ time was nonsignificant in the model and is therefore not reported here. Cow BW recorded at the start of the study was included as a covariate in the model. Statistically significant differences between least squares means were tested using the PDIFF command incorporating the Tukey test for pairwise comparison of treatment means. The model was adjusted for multicomparisons using Bonferroni correction. Repeated measures (week) and random effects (cow) were also included in the model. Statistical significance was assumed at $P<0.05$, and a tendency toward significance was assumed at $P>0.05$ but $P<$ 0.10 .

\section{RESULTS}

\section{DMI, Feed Efficiency, Milk Production, Milk Composition, and BCS}

Period 1. Table 3 shows the effect of treatment on DMI, feed efficiency, milk production, milk composition, and BCS of cows. Pasture DMI was not affected by treatment; however, total DMI was increased by offering $\mathrm{B}(P=0.001)$, $\mathrm{O}(P<0.001)$, or $\mathrm{O}+\mathrm{T}(P$ $<0.001$ ) compared with $\mathrm{C}$. Offering $\mathrm{B}, \mathrm{O}$, or $\mathrm{O}+\mathrm{T}$ reduced feed efficiency ( $\mathrm{kg}$ of $\mathrm{ECM} / \mathrm{kg}$ of total DMI) compared with $\mathrm{C}(P<0.02)$.

Cows on $\mathrm{C}$ had a lower milk yield than those on $\mathrm{B}$ $(P<0.001)$, $\mathrm{O}(P<0.001)$, or $\mathrm{O}+\mathrm{T}(P<0.001)$. Milk fat yield was also lower for $\mathrm{C}$ than for $\mathrm{B}(P=0.03)$, $\mathrm{O}(P<0.001)$, or $\mathrm{O}+\mathrm{T}(P=0.001)$, and $\mathrm{O}$ was associated with a higher milk fat yield compared with $\mathrm{B}$ $(P=0.01 ;$ Figure 2$)$. The $\mathrm{C}$ treatment had lower milk protein, milk casein, and milk lactose yields than B ( $P$ $<0.001)$, $\mathrm{O}(P<0.001)$, or $\mathrm{O}+\mathrm{T}(P<0.001)$. Milk fat + protein yield was lower for $\mathrm{C}$ than for $\mathrm{B}(P<0.001)$, $\mathrm{O}(P<0.001)$, or $\mathrm{O}+\mathrm{T}(P<0.001)$, and $\mathrm{O}$ tended to have higher milk fat + protein yield than $\mathrm{B}(P=0.08$; Figure 3).

Cows offered $\mathrm{C}$ and $\mathrm{O}$ had a higher milk fat concentration compared with $\mathrm{B}(P=0.001)$, and $\mathrm{O}$ tended to have a higher milk fat concentration than $\mathrm{O}+\mathrm{T}(P=$ 0.05). Milk lactose concentration of $\mathrm{C}$ and $\mathrm{B}$ was lower than that of $\mathrm{O}$ and $\mathrm{O}+\mathrm{T}(P<0.002)$. The $\mathrm{B}$ treatment had higher MUN than $\mathrm{C}(P=0.006), \mathrm{O}(P=0.003)$, or $\mathrm{O}+\mathrm{T}(P=0.04$; Figure 4$)$. Energy-corrected milk, FCM, and FPCM yields were lower for C compared with B $(P<0.001), \mathrm{O}(P<0.001)$, and $\mathrm{O}+\mathrm{T}(P<$ $0.001)$.

Period 2. The effects of treatment on DMI, feed efficiency, milk production, milk composition, and BCS of cows in P2, as shown in Table 4, were minimal. Cows offered $\mathrm{O}+\mathrm{T}$ had a higher milk lactose concentration than those offered $\mathrm{C}(P=0.005)$ or $\mathrm{B}(P=0.01)$. Cows offered $\mathrm{O}$ had higher milk fat concentration than cows 
Table 3. The effect of treatment on DMI, feed efficiency, milk production, milk composition, and BCS of cows in period $1^{1}$

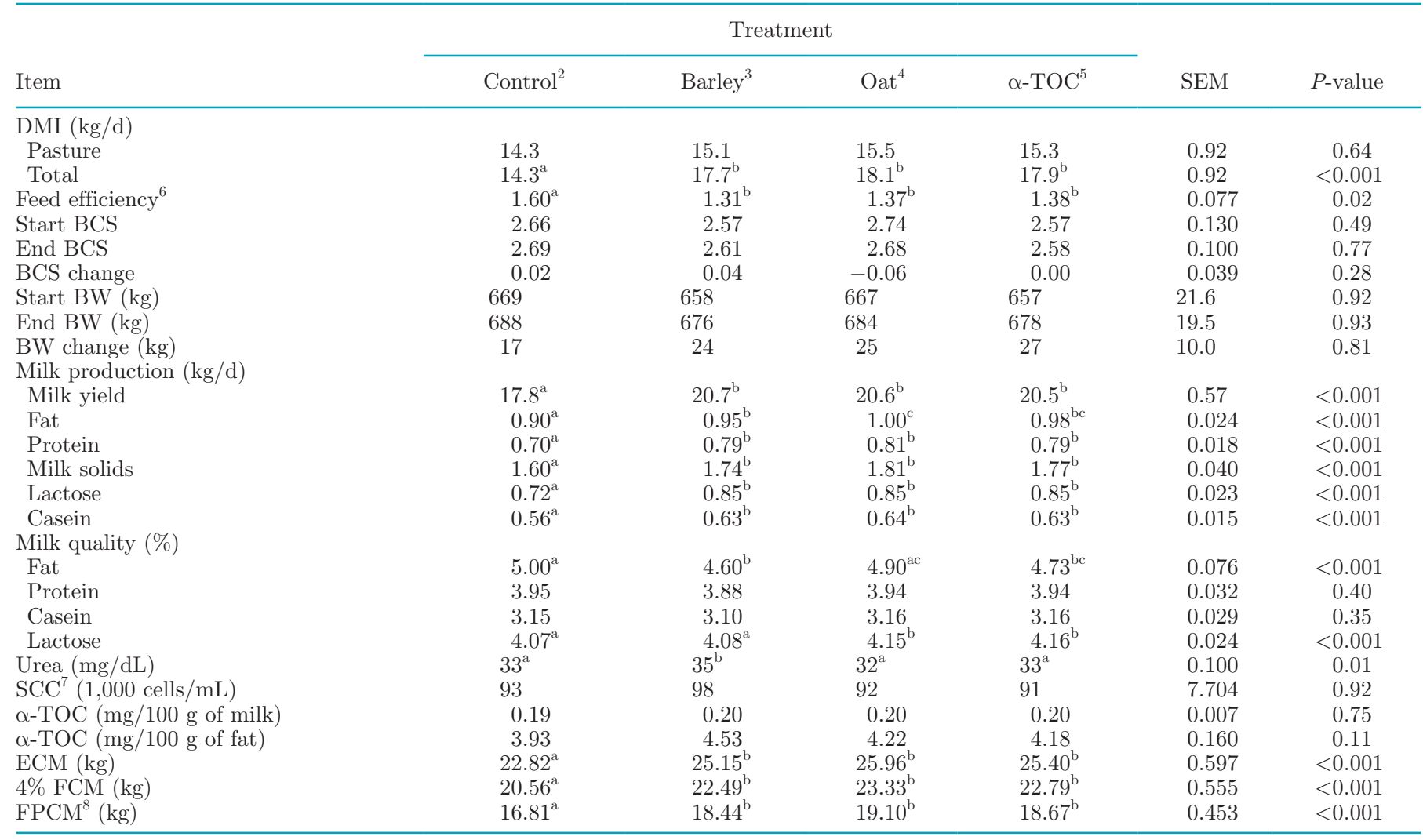

${ }^{\mathrm{a}-\mathrm{c}}$ Within a row, means with different superscripts differ $(P<0.05)$.

${ }^{1}$ Period $1=$ cows at pasture for $49 \mathrm{~d}$.

${ }^{2}$ Base diet of $17 \mathrm{~kg}$ of DM pasture allocation per day.

${ }^{3}$ Base diet $+2.65 \mathrm{~kg}$ of DM of barley-based concentrate $+350 \mathrm{IU}$ of $\alpha$-tocopherol $(\alpha-\mathrm{TOC} / \mathrm{kg})$.

${ }^{4}$ Base diet $+2.65 \mathrm{~kg}$ of DM of oat-based concentrate $+350 \mathrm{IU}$ of $\alpha-\mathrm{TOC} / \mathrm{kg}$.

${ }^{5}$ Base diet $+2.65 \mathrm{~kg}$ of $\mathrm{DM}$ of oat-based concentrate $+1,050 \mathrm{IU}$ of $\alpha-\mathrm{TOC} / \mathrm{kg}$.

${ }^{6} \mathrm{Feed}$ efficiency $=\mathrm{kg}$ of ECM $/ \mathrm{kg}$ of total DMI.

${ }^{7}$ For SCC the natural logarithm transformation data were used to calculate $P$-values. The corresponding least squares means and standard errors of the non-transformed data are presented in results for clarity.

${ }^{8}$ Fat- and protein-corrected milk.

on $\mathrm{C}(P=0.02)$ and tended to have a higher milk fat concentration than those on $\mathrm{O}+\mathrm{T}(P=0.05)$. Cows offered $\mathrm{B}$ tended to have a higher milk fat concentration than those on $\mathrm{C}(P=0.05)$.

\section{Rumen Fermentation and Blood Glucose}

Period 1. Concentrate supplementation reduced rumen $\mathrm{pH}$ (Table 5) compared with $\mathrm{C}(P=0.001)$, whereas $\mathrm{O}+\mathrm{T}$ led to a higher ruminal $\mathrm{pH}$ and lower rumen $\mathrm{NH}_{3}$ concentration compared with $\mathrm{O}(P=0.04$, $P=0.01$, respectively). Treatment $\mathrm{O}+\mathrm{T}$ also had a lower rumen $\mathrm{NH}_{3}$ compared with $\mathrm{C}(P=0.002)$. The $\mathrm{C}$ treatment had lower total VFA concentration compared with $\mathrm{B}(P=0.002)$ and $\mathrm{O}(P=0.006)$ and a higher acetic-to-propionic acid ratio compared with $\mathrm{B}$
$(P=0.03)$. Rumen acetic acid and propionic acid concentrations were increased by B $(P=0.004, P=0.002$, respectively) and $\mathrm{O}(P=0.01, P=0.007$, respectively $)$ compared with $\mathrm{C}$. Cows offered $\mathrm{O}$ had a higher concentration of butyric acid than those offered $\mathrm{C}(P<0.001)$ and $\mathrm{O}+\mathrm{T}(P=0.03)$. However, rumen fermentation parameters did not differ between $\mathrm{O}$ and $\mathrm{B}(P>0.13)$. When propionic acid was expressed as a proportion of total VFA, propionic acid of cows offered $\mathrm{B}$ was higher than in cows offered $\mathrm{C}(P=0.01)$.

Period 2. Treatment had minimal effects on blood glucose concentration and rumen fermentation parameters of cows in P2. Cows offered $\mathrm{O}+\mathrm{T}$ had a higher ruminal $\mathrm{pH}$ compared with $\mathrm{C}(P=0.04)$ and $\mathrm{B}(P=$ $0.001)$, and $\mathrm{O}$ led to a higher ruminal $\mathrm{pH}$ compared with B $(P=0.02$; Table 6$)$. 


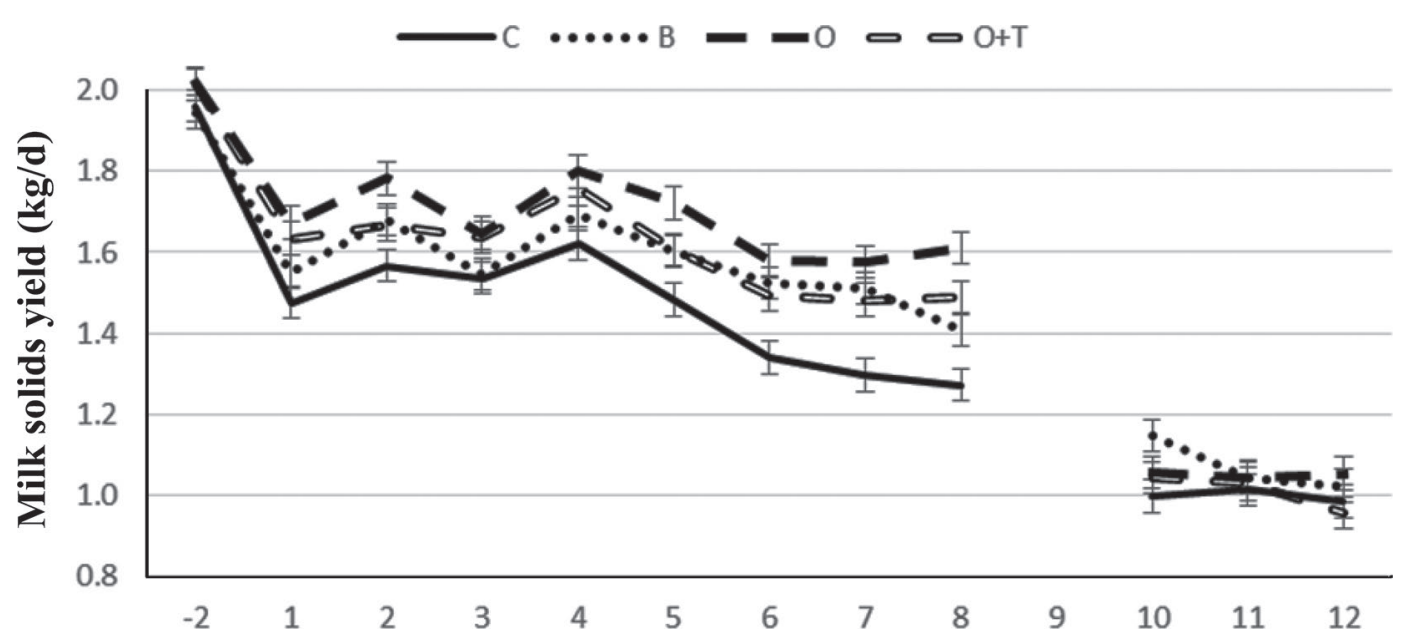

Figure 3. Changes in milk solids yield from the acclimation period (wk -2) over the 8 wk of period 1 (P1; wk 1-8: September 12 to October 31, 2017), acclimation (wk 9 when milk samples were not taken), and 3 wk of period 2 (P2; wk 10-12: November 14-27, 2017). Control, pasture only (C); pasture $+2.65 \mathrm{~kg}(\mathrm{DM})$ of barley-based concentrate $+350 \mathrm{IU}$ of $\alpha$-tocopherol $(\alpha$-TOC) $/ \mathrm{kg}(\mathrm{B})$; pasture $+2.65 \mathrm{~kg}(\mathrm{DM})$ of oat-based concentrate $+350 \mathrm{IU}$ of $\alpha-\mathrm{TOC} / \mathrm{kg}(\mathrm{O})$; pasture $+2.65 \mathrm{~kg}(\mathrm{DM})$ of oat-based concentrate $+1,050 \mathrm{IU}$ of $\alpha-\mathrm{TOC} / \mathrm{kg}(\mathrm{O}+\mathrm{T})$. Error bars detail SEM.

\section{Nitrogen Partitioning Study}

Feed $\mathrm{N}$ intake (Table 7) was increased by offering $\mathrm{B}(P=0.005), \mathrm{O}(P=0.002)$, or $\mathrm{O}+\mathrm{T}(P=0.003)$ compared with C. Offering B $(P=0.003)$, O $(P=$ $0.001)$, or $\mathrm{O}+\mathrm{T}(P=0.002)$ increased urinary N excretion compared with $\mathrm{C}$. The proportion of ingested $\mathrm{N}$ excreted into urine was increased by offering $\mathrm{B}(P=$ $0.04), \mathrm{O}(P=0.02)$, and $\mathrm{O}+\mathrm{T}(P=0.04)$ compared with $\mathrm{C}$.

\section{DISCUSSION}

The objective of this research was to investigate the effect of cereal type and $\alpha$-TOC level on milk yield, milk composition, rumen fermentation, and $\mathrm{N}$ excretion in late-lactation dairy cows at pasture and when housed indoors on grass silage. Therefore, the $\alpha$-TOC intake levels (738 and 2,931 IU of $\alpha$-TOC/d) were selected based on multiple studies in which similar supplemented levels were offered, ranging from 700 to $3,000 \mathrm{IU} / \mathrm{d}$,

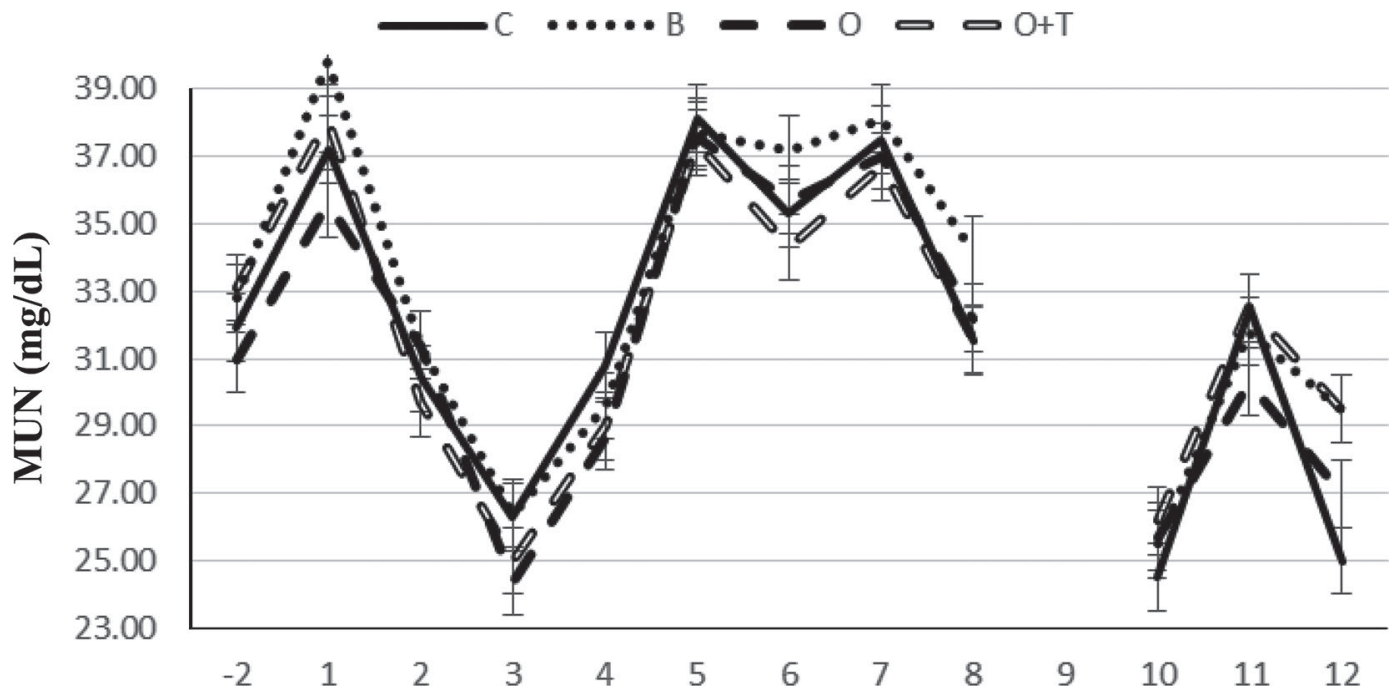

Figure 4. Changes in MUN from the acclimation period (wk -2) over the 8 wk of period 1 (P1; wk 1-8: September 12 to October 31), acclimation (wk 9 when milk samples were not taken), and 3 wk of period 2 (P2; wk 10-12: November 14-27, 2017). Control, pasture only (C); pasture $+2.65 \mathrm{~kg}(\mathrm{DM})$ of barley-based concentrate $+350 \mathrm{IU}$ of $\alpha$-tocopherol $(\alpha$-TOC) $/ \mathrm{kg}(\mathrm{B})$; pasture $+2.65 \mathrm{~kg}(\mathrm{DM})$ of oat-based concentrate $+350 \mathrm{IU}$ of $\alpha-\mathrm{TOC} / \mathrm{kg}(\mathrm{O})$; pasture $+2.65 \mathrm{~kg}(\mathrm{DM})$ of oat-based concentrate $+1,050 \mathrm{IU}$ of $\alpha$-TOC $/ \mathrm{kg}(\mathrm{O}+\mathrm{T})$. Error bars detail SEM. 
Table 4. The effect of treatment on DMI, feed efficiency, milk production, milk composition, and BCS of cows in period $2^{1}$

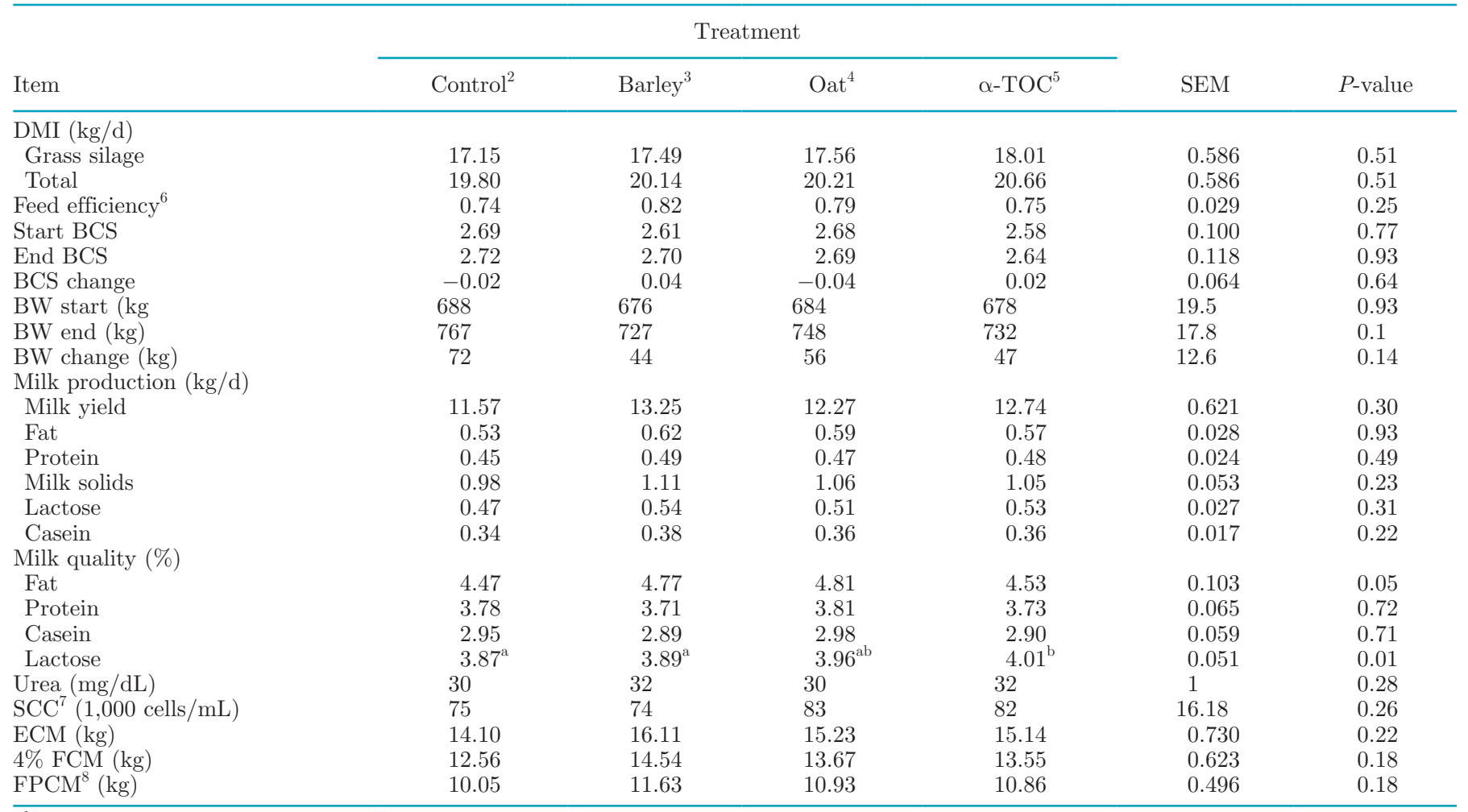

${ }_{\mathrm{a}, \mathrm{b}}$ Within a row, means with different superscripts differ $(P<0.05)$.

${ }^{1}$ Period $2=$ cows indoors for $21 \mathrm{~d}$ offered grass silage.

${ }^{2}$ Base diet, grass silage $+2.65 \mathrm{~kg}$ of $\mathrm{DM}$ of standard concentrate.

${ }^{3}$ Base diet $+2.65 \mathrm{~kg}$ of DM of barley-based concentrate $+350 \mathrm{IU}$ of $\alpha$-tocopherol $(\alpha-\mathrm{TOC}) / \mathrm{kg}$.

${ }^{4}$ Base diet $+2.65 \mathrm{~kg}$ of DM of oat-based concentrate $+350 \mathrm{IU}$ of $\alpha-\mathrm{TOC} / \mathrm{kg}$.

${ }^{5}$ Base diet $+2.65 \mathrm{~kg}$ of DM of oat-based concentrate $+1,050 \mathrm{IU}$ of $\alpha-\mathrm{TOC} / \mathrm{kg}$.

${ }^{6}$ Feed efficiency $=\mathrm{kg}$ of ECM $/ \mathrm{kg}$ of total DMI.

${ }^{7}$ For SCC the natural logarithm transformation data were used to calculate $P$-values. The corresponding least squares means and standard errors of the non-transformed data are presented in results for clarity.

${ }^{8}$ Fat- and protein-corrected milk.

and benefits were observed in terms of reduced SCC (Baldi et al., 2000; Politis et al., 2004), increased milk fat concentration (Charmley and Nicholson, 1993), reduced oxidized flavor (Charmley and Nicholson, 1993), increased milk $\alpha$-TOC concentration (St-Laurent et al., 1990; Charmley and Nicholson, 1993; Baldi et al., 2000), and reduced plasmin activity (Politis et al., 2004). Furthermore, benefits of $\alpha$-TOC supplementation on mammary gland health have been reported for both lactating and nonlactating cows at a minimum of 1,000 IU/d (Hogan et al., 1993, 1996; Smith et al., 1997). It is, however, important to note that grazing dairy cows had a higher basal level of $\alpha$-TOC compared with cows offered hay or silage as in the aforementioned studies. In the current study, supplemental $\alpha$-TOC was provided in a grazing system. The actual levels of $\alpha$-TOC tested in the concentrate feed were lower than those formulated at 259, 246, and $977 \mathrm{IU}$ of $\alpha-\mathrm{TOC} / \mathrm{kg}$, which amounted to 777,738 , and $2,931 \mathrm{IU}$ of $\alpha-\mathrm{TOC} / \mathrm{d}$ for barley, oats, and $\alpha$-TOC, respectively.

\section{DMI, Milk Production, and Milk Composition}

Some studies have shown a reduction in pasture DMI with concentrate feeding (Walker et al., 2001; Bargo et al., 2002); however, we did not observe such a reduction in this research, which may have been due to the low pasture DMI observed. Despite cows being offered $17 \mathrm{~kg}$ of $\mathrm{DM} / \mathrm{d}$, pasture DMI was significantly lower across all treatments, with the pasture-only cows consuming just $14.3 \mathrm{~kg} / \mathrm{d}$ during the measurement period. Based on the high postgrazing residuals, the intake of cows was clearly not restricted (Macdonald et al., 2008; Roche et al., 2009). Voluntary feed intake has been well 
Table 5. The effect of treatment on blood glucose concentration and rumen fermentation parameters of cows in period $1^{1}$

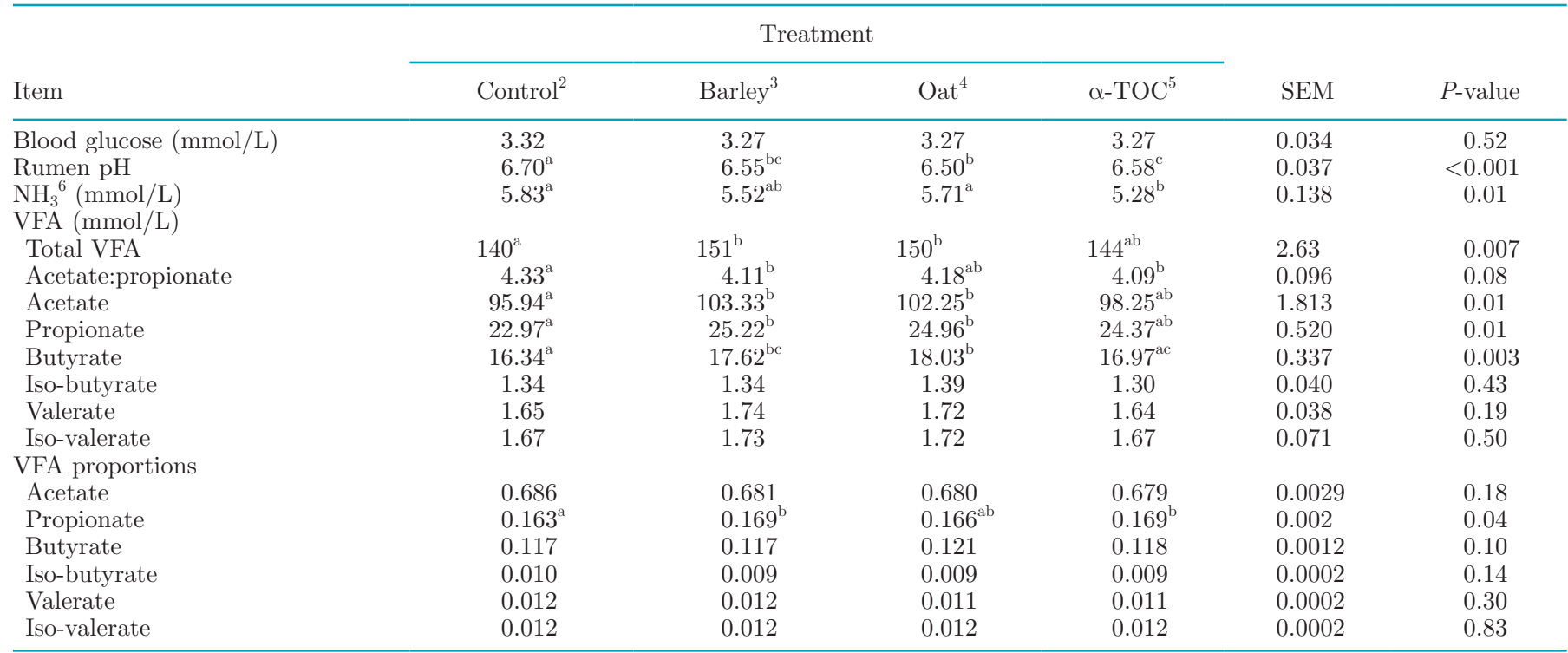

${ }^{\mathrm{a}-\mathrm{c}}$ Within a row, means with different superscripts differ $(P<0.05)$.

${ }^{1}$ Period 1 = cows at pasture for $49 \mathrm{~d}$.

${ }^{2}$ Base diet of $17 \mathrm{~kg}$ of DM pasture allocation per day.

${ }^{3}$ Base diet $+2.65 \mathrm{~kg}$ of DM of barley-based concentrate $+350 \mathrm{IU}$ of $\alpha$-tocopherol $(\alpha-\mathrm{TOC}) / \mathrm{kg}$.

${ }^{4}$ Base diet $+2.65 \mathrm{~kg}$ of $\mathrm{DM}$ of oat-based concentrate $+350 \mathrm{IU}$ of $\alpha-\mathrm{TOC} / \mathrm{kg}$.

${ }^{5}$ Base diet $+2.65 \mathrm{~kg}$ of DM of oat-based concentrate $+1,050 \mathrm{IU}$ of $\alpha-\mathrm{TOC} / \mathrm{kg}$.

${ }^{6}$ Rumen $\mathrm{NH}_{3}$.

Table 6. The effect of treatment on blood glucose concentration and rumen fermentation parameters of cows in period $2^{1}$

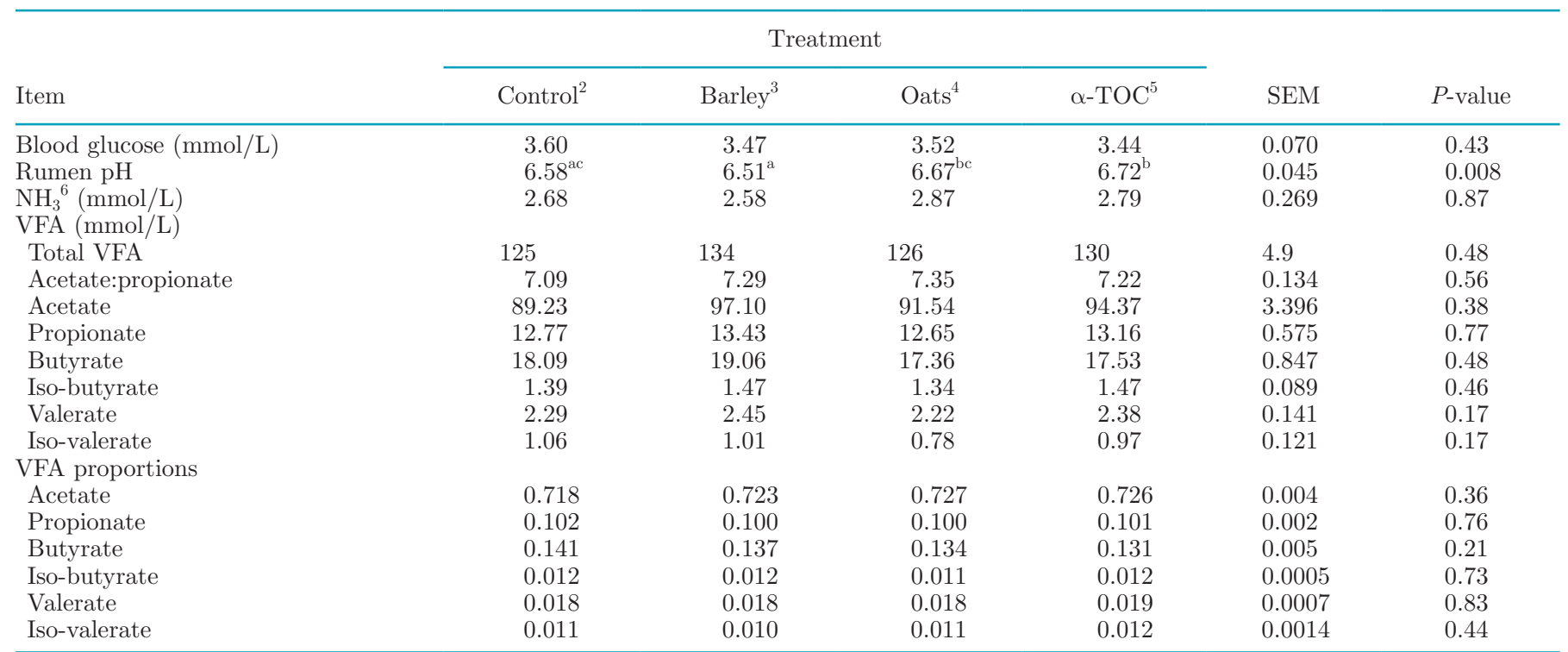

${ }^{\mathrm{a}-\mathrm{c}}$ Within a row, means with different superscripts differ $(P<0.05)$.

${ }^{1}$ Period 2 = cows indoors for $21 \mathrm{~d}$ offered grass silage.

${ }^{2}$ Base diet, grass silage $+2.65 \mathrm{~kg}$ of DM of standard concentrate.

${ }^{3}$ Base diet $+2.65 \mathrm{~kg}$ of DM of barley-based concentrate $+350 \mathrm{IU}$ of $\alpha$-tocopherol $(\alpha-\mathrm{TOC}) / \mathrm{kg}$.

${ }^{4}$ Base diet $+2.65 \mathrm{~kg}$ of DM of oat-based concentrate $+350 \mathrm{IU}$ of $\alpha$-TOC $/ \mathrm{kg}$.

${ }^{5}$ Base diet $+2.65 \mathrm{~kg}$ of DM of oat-based concentrate $+1,050 \mathrm{IU}$ of $\alpha-\mathrm{TOC} / \mathrm{kg}$.

${ }^{6}$ Rumen $\mathrm{NH}_{3}$. 
documented to be influenced by several feed characteristics such as dietary NDF and CP content (McDonald et al., 2001). In a study similar to ours, Reid et al. (2015) allocated late-lactation dairy cows $14 \mathrm{~kg}$ DM/d of autumn pasture and observed a higher pasture DMI of $16.5 \mathrm{~kg}$ of $\mathrm{DM} / \mathrm{d}$. A potential explanation for the difference in pasture DMI between the studies may be related to the difference in autumn pasture quality in the current study $(135 \mathrm{~g} / \mathrm{kg} \mathrm{DM}, 217 \mathrm{~g} / \mathrm{kg} \mathrm{CP}$, and $499 \mathrm{~g} / \mathrm{kg}$ DM NDF) compared with that of Reid et al. (2015), who reported a higher DM, CP, and lower NDF content (141 g/kg DM, $274 \mathrm{~g} / \mathrm{kg} \mathrm{CP}$, and $377 \mathrm{~g} / \mathrm{kg} \mathrm{DM}$ $\mathrm{NDF}$ ). The combined effect of a lower NDF and a high CP content in Reid et al. (2015) possibly increased the rate of NDF degradability and rumen passage (Costa et al., 2008) and therefore may have resulted in an increased pasture DMI compared with the current study.

When pasture DMI is reduced as a result of concentrate feeding, it is referred to as substitution rate $(\mathrm{kg}$ reduction in pasture DMI per kg of DMI of concentrate; Kellaway and Harrington, 2004). However, with pasture DMI being low in the pasture-only treatment in this study, no substitution rate was observed. When concentrate supplementation was subsequently offered, total DMI was increased significantly. Other studies have also reported no substitution rate with low pasture allowances of 13 to $14 \mathrm{~kg}$ of DM/cow per day and concentrate supplementation of approximately $3 \mathrm{~kg}$ of $\mathrm{DM} / \mathrm{d}$ in early lactation (McEvoy et al., 2008) and late lactation (Reid et al., 2015). Substitution rate is a major factor that contributes to milk response to concentrate supplementation (the difference in milk produced between unsupplemented and supplemented treatment divided by concentrate DMI), with milk response and concentrate supplementation being negatively correlated (Kellaway and Porta, 1993). Therefore, with no substitution rate observed, an average milk response of $1.06 \mathrm{~kg}$ of milk $/ \mathrm{kg}$ of concentrate supplemented was calculated, which is within the range of 0.5 to $1.18 \mathrm{~kg}$ of milk $/ \mathrm{kg}$ of concentrate reported in other studies for late-lactation cows (Gleeson, 1981; Mackle et al., 1999; Lovett et al., 2005).

Different concentrate types can influence milk production and composition (Sutton, 1989), as seen in the current study, with oat grain supplementation maintaining milk production and increasing milk fat concentration compared with barley for late-lactation cows at pasture. Milk yield, FCM yield, and milk solids yield of cows at pasture were increased by both barley and oats compared with those of cows offered pasture only, as might be expected due to the increased energy intake (Jeffery et al., 1976; Kellaway and Porta, 1993; Reid et al., 2015). However, little information is available on oat supplementation at pasture. An early study by Jeffery et al. (1976) also observed no difference in FCM yield between cows supplemented with $3 \mathrm{~kg} / \mathrm{d}$ of barley or oat grain, but differences in the study duration time (14 d), pasture species (tropical grasses and legumes),

Table 7 . The effect of treatment on partitioning of nitrogen $(\mathrm{N})$ in period $1^{1}$

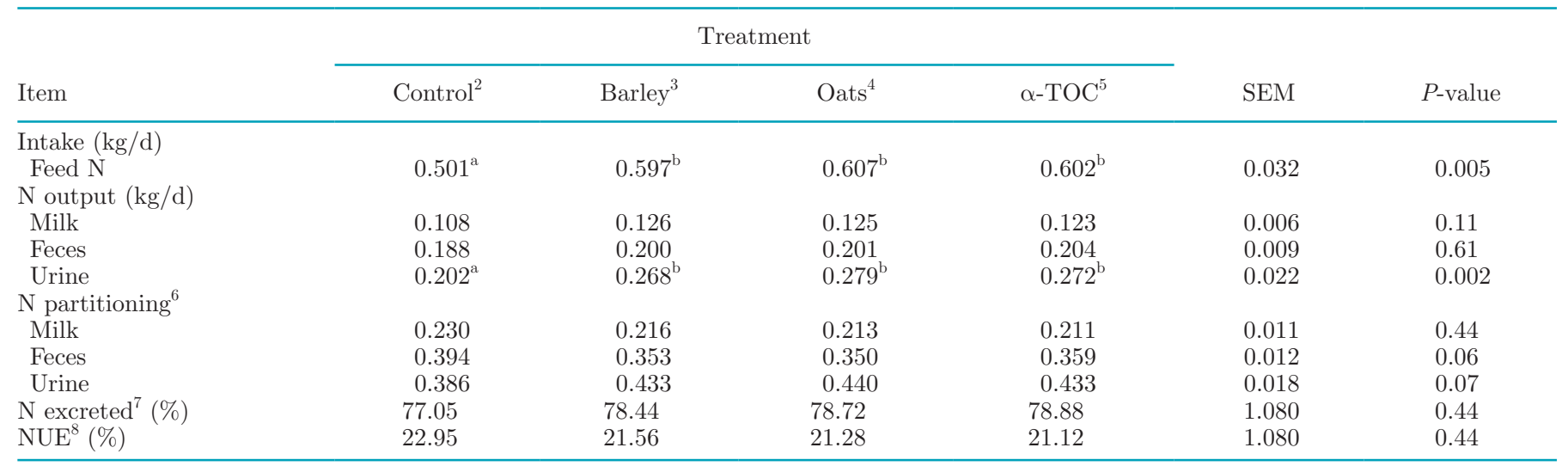

${ }^{\mathrm{a}, \mathrm{b}}$ Within a row, means with different superscripts differ $(P<0.05)$.

${ }^{1}$ Period 1 = cows at pasture for $49 \mathrm{~d}$.

${ }^{2}$ Base diet of $17 \mathrm{~kg}$ of DM pasture allocation per day.

${ }^{3}$ Base diet $+2.65 \mathrm{~kg}$ of DM of barley-based concentrate $+350 \mathrm{IU}$ of $\alpha$-tocopherol $(\alpha-\mathrm{TOC}) / \mathrm{kg}$.

${ }^{4}$ Base diet $+2.65 \mathrm{~kg}$ of DM of oat-based concentrate $+350 \mathrm{IU}$ of $\alpha-\mathrm{TOC} / \mathrm{kg}$.

${ }^{5}$ Base diet $+2.65 \mathrm{~kg}$ of DM of oat-based concentrate $+1,050 \mathrm{IU}$ of $\alpha-\mathrm{TOC} / \mathrm{kg}$.

${ }^{6} \mathrm{~N}$ partitioning $=\mathrm{N}$ out $[$ feces, urine, milk $(\mathrm{kg} / \mathrm{d})] / \mathrm{N}$ intake $(\mathrm{kg} / \mathrm{d})$.

${ }^{7} \mathrm{~N}$ excreted $=[$ feces + urine output $(\mathrm{kg} / \mathrm{d})] / \mathrm{N}$ intake $(\mathrm{kg} / \mathrm{d}) \times 100$.

${ }^{8} \mathrm{NUE}=[$ milk output $(\mathrm{kg} / \mathrm{d})] / \mathrm{N}$ intake $(\mathrm{kg} / \mathrm{d}) \times 100$. 
and breed of cow (Jersey and Australian shorthorn) exist between the studies. Although barley is a higher energy cereal than oats (Ewing, 1997), at the inclusion level in the concentrate $(42 \%)$ of the current study, the starch intake of cows offered barley or oats only differed by $80 \mathrm{~g} / \mathrm{d}$, which is likely not enough to affect milk production. Increasing the starch intake of cows drives the production of propionic acid, a precursor of milk lactose, and subsequently, milk yield (Shamay et al., 2003; Aschenbach et al., 2010). The higher starch intake of cows offered concentrate supplementation (approximately $500 \mathrm{~g} / \mathrm{d}$ ) increased propionate concentration and subsequently milk yield compared with cows offered pasture only.

In pasture-based systems, as concentrate level increases from approximately $2 \mathrm{~kg}$ of $\mathrm{DM} / \mathrm{d}$ up to $10 \mathrm{~kg}$ of $\mathrm{DM} / \mathrm{d}$, milk fat concentration is reduced compared with pasture-only diets (O'Brien et al., 1996; Bargo et al., 2003). In agreement, the present experiment observed a reduction in milk fat concentration with the barley-based supplement. However, the oat-based supplement maintained milk fat concentration similar to that of milk from cows offered pasture only and is supported by the similar acetate-to-propionate ratio. This may be due to the higher NDF content of the oat-based supplement $(349 \mathrm{~g} / \mathrm{kg})$ compared with barley $(314 \mathrm{~g} / \mathrm{kg})$. Lactose levels observed in this study were very low, however, that is not uncommon for spring calving grass-based systems in which milk yield can also be very low.

The majority of research into supplementation with oats has been carried out in confinement systems, with variable milk production responses for oats compared with barley (Moran, 1986). Tommervik and Waldern (1969) observed similar milk production for oats and barley when offered as part of a complete diet. However, other studies have found that dairy cows offered an oat-based concentrate as part of a complete diet had increased milk production compared with a barleybased diet (Moss and Prier, 1981; Moran, 1986; Ekern et al., 2003). When cows were housed and offered grass silage in the present experiment, we observed no difference between the barley and oat treatments, and this finding may be due to the similar energy content of the concentrates offered. Additionally, the silage offered was of high quality (122 g/ kg of ME); a greater difference may have been observed between barley and oats with lower quality silage, such as in Ekern et al. (2003) $(93.2 \mathrm{~g} / \mathrm{kg}$ of ME). Multiple differences exist, however, between the current study and the confinement studies in the literature in terms of basal diets, stage of lactation, concentrate levels, and ingredient inclusion levels, making comparison difficult (Moran, 1986; Ekern et al., 2003).
$\alpha$-Tocopherol plays an important role in cell structure and has been previously reported in other species to improve epithelial cell tight junctions (Charmley et al., 1993; Arreola-Mendoza et al., 2009; Fusi et al., 2018). In dairy cows, as lactation progresses, a reduction occurs in mammary secretory epithelial cells and tight junction structures become leaky, which negatively affects milk yield and alters milk composition (Wilde and Knight, 1989; Nguyen and Neville, 1998; Stefanon et al., 2002; Matter and Balda, 2003). We offered 2 different levels of $\alpha$-TOC (treatment $\mathrm{O}=$ $738 \mathrm{IU}$ of $\alpha-\mathrm{TOC} / \mathrm{d}$ and treatment $\mathrm{O}+\mathrm{T}=2,931 \mathrm{IU}$ of $\alpha$-TOC/d) but observed no difference between the 2 treatments for milk yield, SCC, or milk casein concentration, which suggests that cell structure was not affected by the higher level offered. The high quality of the milk suggests pasture quality and availability were adequate to meet the nutritional requirements of the cows and that tight junction leakiness, which is expected in late lactation, was not an issue for cows in this study.

\section{Rumen Fermentation and Blood Glucose}

Offering concentrate supplementation to dairy cows at pasture increases the starch and subsequent energy intake of cows (Bargo et al., 2002). The reported increase in milk yield from cows offered barley and oats compared with pasture only in this study is likely driven by the increase in propionic acid concentration, a precursor of milk lactose and, therefore, milk yield (Shamay et al., 2003; Aschenbach et al., 2010). In line with the increase in propionate and total VFA concentrations for all supplemented treatments, rumen $\mathrm{pH}$ was reduced as might be expected; however, rumen $\mathrm{pH}$ was above 6.2 , which is considered optimal for fiber digestion (Ørskov, 1999).

The high $\alpha$-TOC $(2,931$ IU of $\alpha$-TOC/d) level during the grazing stage of this study altered some of the rumen fermentation parameters measured, namely $\mathrm{NH}_{3}$ and rumen $\mathrm{pH}$. Although these differences are statistically significant, they are not considered biologically significant given the similar level of milk production and composition from cows offered high and low levels of $\alpha$-TOC. However, Kay et al. (2005) offered a high level of $\alpha$-TOC to dairy cows $(10,000$ IU of $\alpha$-TOC/d) in late lactation as part of a TMR diet and reported reduced plasma urea levels, which suggested a possible reduction in rumen $\mathrm{NH}_{3}$ concentration or a greater utilization of $\mathrm{NH}_{3}$ in the rumen similar to that observed in the current study. Kay et al. (2005) suggested that $\alpha$-TOC may have altered rumen biohydrogenation although the exact mechanisms are not known. High $\alpha$-TOC did alter the milk fatty acid profile in this study 
(data not shown), which would support the suggestion of Kay et al. (2005).

\section{Nitrogen Partitioning Study}

Grazing dairy cows and cows offered fresh or ensiled ryegrass, which is high in $\mathrm{N}$, are particularly inefficient at utilizing ingested N (Vérité and Delaby, 2000). Previous research has found that supplementation at pasture can reduce $\mathrm{N}$ excretion because high $\mathrm{N}$ grass is usually replaced by a lower $\mathrm{N}$ supplement (Whelan et al., 2012b; Reid et al., 2015). However, in this research, with pasture intake being similar across all treatments, dietary $\mathrm{N}$ intake was increased in the supplemented treatments. Although the total $\mathrm{N}$ excreted was not affected by treatment and was within the reference range of 70 to $80 \%$ of ingested N (Ryan et al., 2011), concentrate supplementation increased urinary $\mathrm{N}$ excretion. However, error may have occurred in the measurement of urinary $\mathrm{N}$ because it is calculated by difference: urinary $\mathrm{N}=\mathrm{N}$ intake $(\mathrm{g})-$ fecal $\mathrm{N}(\mathrm{g})-$ milk $\mathrm{N}(\mathrm{g})$. From an environmental perspective, however, increased urinary $\mathrm{N}$ from increased $\mathrm{N}$ intake is not desirable because urinary $\mathrm{N}$ can be volatilized into the atmosphere as $\mathrm{NH}_{3}$ or lost through leaching in the soil (Castillo, 2001; Ryan et al., 2011).

\section{CONCLUSIONS}

Concentrate supplementation increased milk yield and milk solids yield. Oat-based supplementation had a similar milk yield and a higher milk fat concentration in comparison to the barley-based supplement offered at pasture. Increasing the level of $\alpha$-TOC did not alter milk yield or milk composition parameters; however, a reduction in rumen $\mathrm{NH}_{3}$ concentration was observed for grazing dairy cows. Cereal type and $\alpha$-TOC level did not affect milk production or composition when cows were offered grass silage.

\section{ACKNOWLEDGMENTS}

Funding for this research was provided under the Innovative Dairy Production Systems and Technologies (DairyTech) Innovation Partnership Programme through the Enterprise Ireland Innovative Partnership program, which is cofunded by the European Regional Development Fund under Ireland's European Structural and Investment Funds Programmes 2014-2020. Additionally, the authors acknowledge the contribution of the farm and laboratory staff at UCD Lyons Research Farm.

\section{REFERENCES}

Al Ibrahim, R. M., A. K. Kelly, L. O'Grady, V. P. Gath, C. McCarney, and F. J. Mulligan. 2010. The effect of body condition score at calving and supplementation with Saccharomyces cerevisiae on milk production, metabolic status, and rumen fermentation of dairy cows in early lactation. J. Dairy Sci. 93:5318-5328.

AOAC International. 2005. Official Methods of Analysis. 18th ed. AOAC International, Gaithersburg, MD.

Arreola-Mendoza, L., L. M. Del Razo, M. E. Mendoza-Garrido, D. Martin, M. C. Namorado, J. V. Calderon-Salinas, and J. L. Reyes. 2009. The protective effect of alpha-tocopherol against dichromate-induced renal tight junction damage is mediated via ERK1/2. Toxicol. Lett. 191:279-288.

Aschenbach, J. R., N. B. Kristensen, S. S. Donkin, H. M. Hammon, and G. B. Penner. 2010. Gluconeogenesis in dairy cows: The secret of making sweet milk from sour dough. IUBMB Life 62:869-877.

Baldi, A., G. Savoini, L. Pinotti, E. Monfardini, F. Cheli, and V. D. Orto. 2000. Effects of vitamin $\mathrm{E}$ and different energy sources on vitamin E status, milk quality and reproduction in transition cows. J. Vet. Med. A Physiol. Pathol. Clin. Med. 47:599-608.

Bargo, F., L. Muller, E. Kolver, and J. Delahoy. 2003. Invited review: Production and digestion of supplemented dairy cows on pasture. J. Dairy Sci. 86:1-42.

Bargo, F., L. D. Muller, J. E. Delahoy, and T. W. Cassidy. 2002. Milk response to concentrate supplementation of high producing dairy cows grazing at two pasture allowances. J. Dairy Sci. 85:1777-1792.

Burke, F., M. O'Donovan, J. Murphy, F. O'Mara, and F. Mulligan. 2008. Effect of pasture allowance and supplementation with maize silage and concentrates differing in crude protein concentration on milk production and nitrogen excretion by dairy cows. Livest. Sci. 114:325-335.

Castillo, A. 2001. Improving nitrogen utilisation in dairy cows. PhD Thesis. University of Reading, UK.

Charmley, E., and J. W. G. Nicholson. 1993. Injectable $\alpha$-tocopherol for control of oxidized flavour in milk from dairy cows. Can. J. Anim. Sci. 73:381-392.

Charmley, E., J. W. G. Nicholson, and J. A. Zee. 1993. Effect of supplemental vitamin $\mathrm{E}$ and selenium in the diet on vitamin $\mathrm{E}$ and selenium levels and control of oxidized flavour in milk from Holstein cows. Can. J. Anim. Sci. 73:453-457.

Costa, V. A. C., E. Detmann, S. D. C. Valadares Filho, M. F. Paulino, L. T. Henriques, and H. C. Mantovani. 2008. In vitro degradation of neutral detergent fiber from low-quality tropical forage as a function of protein and/or protein supplementation, or carbohydrates. Rev. Bras. Zootec. 37:494-503.

CSO (Central Statistics Office). 2015. Milk Statistics, December 2015. Accessed Feb. 10, 2018. https://www.cso.ie/ en/releasesandpublications/er/ms/milkstatisticsdecember2015.

CSO (Central Statistics Office). 2017. Agriculture Selected Livestock numbers in December 2017. Accessed Feb. 10, 2018. https://www .cso.ie/multiquicktables/quickTables.aspx?id=aaa06.

Dove, H., and R. W. Mayes. 2006. Protocol for the analysis of $n-a l-$ kanes and other plant-wax compounds and for their use as markers for quantifying the nutrient supply of large mammalian herbivores. Nat. Protoc. 1:1680-1697.

Downey, L., and P.T. Doyle. 2007. Cow nutrition and dairy product manufacture - Implications of seasonal pasture-based milk production systems. Aust. J. Dairy Technol. 62:3-11.

Dubois, M., K. A. Gilles, J. K. Hamilton, P. T. Rebers, and F. Smith. 1956. Colorimetric method for determination of sugars and related substances. Anal. Chem. 28:350-356.

Edmonson, A. J., I. J. Lean, L. D. Weaver, T. Farver, and G. Webster. 1989. A body condition scoring chart for Holstein dairy cows. J. Dairy Sci. 72:68-78.

Ekern, A., Ø. Havrevoll, A. Haug, J. Berg, P. Lindstad, and S. Skeie. 2003. Oat and barley based concentrate supplements for dairy cows. Acta Agric. Scand. Sect. A Anim. Sci. 53:65-73.

Ewing, W. N. 1997. The Feeds Directory. Volume 1: Commodity Products. Context Publications, Leicestershire, UK. 
Fusi, E., C. Giromini, R. Rebucci, L. Pinotti, V. Caprarulo, F. Cheli, F. Vitari, C. Domeneghini, and A. Baldi. 2018. Ochratoxin A cytotoxicity on Madin-Darby canine kidney cells in the presence of alpha-tocopherol: Effects on cell viability and tight junctions. J. Anim. Physiol. Anim. Nutr. (Berl.) 102:350-355.

Gaines, W. L., and F. A. Davidson. 1923. Relation between percentage fat content and yield of milk, correction of milk yield for fat content. Pages 577-621 in Agric. Exp. Sta. Bull. 245. Univ. of Illinois Agric. Exp. Stn., Urbana, IL.

Gleeson, P. A. 1981. Concentrate supplementation for spring calving cows. Grass Forage Sci. 36:138-141.

Hackett, R. 2018. A comparison of husked and naked oats under Irish conditions. Ir. J. Agric. Food Res. 57:1-8.

Hanrahan, L., A. Geoghegan, M. O'Donovan, V. Griffith, E. Ruelle, M. Wallace, and L. Shalloo. 2017. PastureBase Ireland: A grassland decision support system and national database. Comput. Electron. Agric. 136:193-201.

Hogan, J. S., W. P. Weiss, and K. L. Smith. 1993. Role of vitamin $\mathrm{E}$ and selenium in host defense against mastitis. J. Dairy Sci. 76:2795-2803.

Hogan, J. S., W. P. Weiss, K. L. Smith, L. M. Sordillo, and S. N. Williams. 1996. a-Tocopherol concentrations in milk and plasma during clinical Escherichia coli mastitis. J. Dairy Sci. 79:71-75.

Jeffery, H., R. F. Buesnel, and G. H. O'Neill. 1976. Short-term studies on the response of grazing dairy cows to dietary supplementation. Aust. J. Exp. Agric. 16:445-451.

Kay, J. K., J. R. Roche, E. S. Kolver, N. A. Thomson, and L. H. Baumgard. 2005. A comparison between feeding systems (pasture and TMR) and the effect of vitamin E supplementation on plasma and milk fatty acid profiles in dairy cows. J. Dairy Res. 72:322-332.

Kellaway, R., and T. Harrington. 2004. Feeding Concentrates: Supplements for Dairy Cows. Landlinks Press, Melbourne, Australia.

Kellaway, R., and S. Porta. 1993. Feeding Concentrates: Supplements for Dairy Cows. Dairy Res. Dev. Corp., Australia.

Kennedy, E., M. O'Donovan, J. P. Murphy, L. Delaby, and F. O'Mara. 2005. Effects of grass pasture and concentrate-based feeding systems for spring-calving dairy cows in early spring on performance during lactation. Grass Forage Sci. 60:310-318.

Liu, Q., M. C. Lanari, and D. M. Schaefer. 1995. A review of dietary vitamin E supplementation for improvement of beef quality. J. Anim. Sci. 73:3131-3140.

Lovett, D. K., L. J. Stack, S. Lovell, J. Callan, B. Flynn, M. Hawkins, and F. P. O'Mara. 2005. Manipulating enteric methane emissions and animal performance of late-lactation dairy cows through concentrate supplementation at pasture. J. Dairy Sci. 88:2836-2842.

Macdonald, K. A., G. A. Verkerk, B. S. Thorrold, J. E. Pryce, J. W. Penno, L. R. McNaughton, L. J. Burton, J. A. S. Lancaster, J H. Williamson, and C. W. Holmes. 2008. A comparison of three strains of Holstein-Friesian grazed on pasture and managed under different feed allowances. J. Dairy Sci. 91:1693-1707.

Mackle, T. R., A. M. Bryant, S. F. Petch, R. J. Hooper, and M. J. Auldist. 1999. Variation in the composition of milk protein from pasture-fed dairy cows in late lactation and the effect of grain and silage supplementation. N. Z. J. Agric. Res. 42:147-154.

Matter, K., and M. S. Balda. 2003. Signalling to and from tight junctions. Nat. Rev. Mol. Cell Biol. 4:225-236.

McDonald, P., R. A. Edwards, J. F. D. Greenhalgh, and C. A. Morgan. 2001. Animal Nutrition. 6th ed. Pearsons Education, New York, NY.

McDowell, L. R. 2000. Vitamin E. Pages 155-216 in Vitamins in Animal and Human Nutrition. Iowa State University Press, Ames.

McEvoy, M., E. Kennedy, J. P. Murphy, T. M. Boland, L. Delaby, and M. O'Donovan. 2008. The effect of herbage allowance and concentrate supplementation on milk production performance and dry matter intake of spring-calving dairy cows in early lactation. J. Dairy Sci. 91:1258-1269.

McKay, Z. C., M. B. Lynch, F. J. Mulligan, G. Rajauria, and K. M. Pierce. 2017. The effect of concentrate supplementation strategy on milk production and rumen fermentation parameters in late lactation spring-calving grazing dairy cows. J. Dairy Sci. 100(Suppl. 2):95. (Abstr.)
Monahan, F. J., D. J. Buckley, J. I. Gray, P. A. Morrissey, A. Asghar, T. J. Hanrahan, and P. B. Lynch. 1990. Effect of dietary vitamin $\mathrm{E}$ on the stability of raw and cooked pork. Meat Sci. 27:99-108.

Moran, J. B. 1986. Cereal grains in complete diets for dairy cows: A comparison of rolled barley, wheat and oats and of three methods of processing oats. Anim. Sci. 43:27-36.

Moss, B. R., and S. G. Prier. 1981. High levels of barley in rations for calves and lactating cows. J. Dairy Sci. 64(Suppl. 1):128. (Abstr.)

Nguyen, D. A. D., and M. C. Neville. 1998. Tight junction regulation in the mammary gland. J. Mammary Gland Biol. Neoplasia 3:233-246.

O'Brien, B., S. Crosse, and P. Dillon. 1996. Effects of offering a concentrate or silage supplement to grazing dairy cows in late lactation on animal performance and on milk processability. Ir. J. Agric. Food Res. 35:113-125.

Ørskov, E. R. 1999. Supplement strategies for ruminants and management of feeding to maximize utilization of roughages. Prev. Vet. Med. 38:179-185.

Phelan, J. A., A. M. O'Keeffe, M. K. Keogh, and P. M. Kelly. 1982. Studies of milk composition and its relationship to some processing criteria: 1. Seasonal changes in the composition of Irish milk. Ir. J. Food Sci. Technol. 6:1-11.

Politis, I., I. Bizelis, A. Tsiaras, and A. Baldi. 2004. Effect of vitamin E supplementation on neutrophil function, milk composition and plasmin activity in dairy cows in a commercial herd. J. Dairy Res. $71: 273-278$.

Putnam, M. E., and N. Comben. 1987. Vitamin E. Vet. Rec. 121:541.

Reid, M., M. O'Donovan, J. P. Murphy, C. Fleming, E. Kennedy, and E. Lewis. 2015. The effect of high and low levels of supplementation on milk production, nitrogen utilization efficiency, and milk protein fractions in late-lactation dairy cows. J. Dairy Sci. 98:5529-5544.

Rice, D. A., and S. Kennedy. 1988. Assessment of vitamin E, selenium and polyunsaturated fatty acid interactions in the aetiology of disease in the bovine. Proc. Nutr. Soc. 47:177.

Roche, J. R., N. C. Friggens, J. K. Kay, M. W. Fisher, K. J. Stafford, and D. P. Berry. 2009. Invited review: Body condition score and its association with dairy cow productivity, health, and welfare. J. Dairy Sci. 92:5769-5801

Ryan, W., D. Hennessy, J. J. Murphy, T. M. Boland, and L. Shalloo. 2011. A model of nitrogen efficiency in contrasting grass-based dairy systems. J. Dairy Sci. 94:1032-1044.

Shamay, A., F. Shapiro, G. Leitner, and N. Silanikove. 2003. Infusions of casein hydrolyzates into the mammary gland disrupt tight junction integrity and induce involution in cows. J. Dairy Sci. $86: 1250-1258$.

Sjaunja, L. O., L. Baevre, L. Junkkarinen, J. Pedersen, and J. Setala. 1990. A Nordic proposal for an energy corrected milk (ECM) formula. Pages 156-192 in Performance Recording of Animals: 27th Biennial Session of the International Committee of Animal Recording, Paris, France. EAAP publication No. 50. Center for Agricultural Publishing and Documentation (Pudoc), Wageningen, the Netherlands.

Smith, K. L., J. S. Hogan, and W. P. Weiss. 1997. Dietary vitamin $\mathrm{E}$ and selenium affect mastitis and milk quality. J. Anim. Sci. $75: 1659-1665$

Soyeurt, H., P. Dardenne, F. Dehareng, G. Lognay, D. Veselko, M. Marlier, C. Bertozzi, P. Mayeres, and N. Gengler. 2006. Estimating fatty acid content in cow milk using mid-infrared spectrometry. J. Dairy Sci. 89:3690-3695.

St-Laurent, A. M., J. W. G. Nicholson, M. Hidiroglou, and M. Snoddon. 1990. Effect of $\alpha$-tocopherol supplementation to dairy cows on milk and plasma $\alpha$-tocopherol concentrations and on spontaneous oxidized flavor in milk. Can. J. Anim. Sci. 70:561-570.

Stefanon, B., M. Colitti, G. Gabai, C. H. Knight, and C. J. Wilde. 2002. Mammary apoptosis and lactation persistency in dairy animals. J. Dairy Res. 69:37-52.

Stelwagen, K., V. C. Farr, H. A. McFadden, C. G. Prosser, and S. R. Davis. 1997. Time course of milk accumulation-induced opening of mammary tight junctions, and blood clearance of milk components. Am. J. Physiol. 273:R379-R386. 
Sutton, J. 1989. Altering milk composition by feeding. J. Dairy Sci. $72: 2801-2814$.

Theurer, C. B. 1986. Grain processing effects on starch utilization by ruminants. J. Anim. Sci. 63:1649-1662.

Tommervik, R. S., and D. E. Waldern. 1969. Comparative feeding value of wheat, corn, barley, milo, oats, and a mixed concentrate ration for lactating cows. J. Dairy Sci. 52:68-73.

Tyrrell, H. F., and J. T. Reid. 1965. Prediction of the energy value of cow's milk. J. Dairy Sci. 48:1215-1223.

Van Soest, P. J., J. B. Robertson, and B. A. Lewis. 1991. Methods for dietary fibre, neutral detergent fibre, and nonstarch polysaccharides in relation to animal nutrition. J. Dairy Sci. 74:3583-3597.

van Vuuren, A. M., C. J. van der Koelen, H. Valk, and H. de Visser. 1993. Effects of partial replacement of ryegrass by low protein feeds on rumen fermentation and nitrogen loss by dairy cows. J. Dairy Sci. 76:2982-2993.

Vérité, R., and L. Delaby. 2000. Relation between nutrition, performances and nitrogen excretion in dairy cows. Ann. Zootech. $49: 217-230$.
Walker, G. P., C. R. Stockdale, W. J. Wales, P. T. Doyle, and D. W. Dellow. 2001. Effect of level of grain supplementation on milk production responses of dairy cows in mid-late lactation when grazing irrigated pastures high in paspalum (Paspalum dilatatum Poir.). Aust. J. Exp. Agric. 41:1-11.

Whelan, S. J., K. M. Pierce, B. Flynn, and F. J. Mulligan. 2012a. Effect of supplemental concentrate type on milk production and metabolic status in early-lactation dairy cows grazing perennial ryegrass-based pasture. J. Dairy Sci. 95:4541-4549.

Whelan, S. J., K. M. Pierce, C. McCarney, B. Flynn, and F. J. Mulligan. 2012b. Effect of supplementary concentrate type on nitrogen partitioning in early lactation dairy cows offered perennial ryegrass-based pasture. J. Dairy Sci. 95:4468-4477.

Wilde, C. J., and C. H. Knight. 1989. Metabolic adaptations in mammary gland during the declining phase of lactation. J. Dairy Sci. $72: 1679-1692$. 